\title{
Effect of Debt Financing on the Corporate Performance: A Study of Listed Consumer Goods firms in Nigeria
}

\author{
${ }^{1}$ Aniefor Sunday Jones, B.sc, M.sc, MBA, ACTI, ACA, CPFA, MCIA, ${ }^{2}$ Onatuyeh Aruobogha Edwin, B.sc, M.sc, MA, ACA, \\ ACTI, FCCA, CPFA, MCIA.
}

\author{
Department of Accountancy. School of Business Studies, Delta State Polytechnic, Ozoro, Delta State, Nigeria \\ lanieforjones@yahoo.com,Tel No:08038741973 \\ 2 edwin.onatuyeh@yahoo.com, Tel No:08032466517
}

(Corresponding Author)

\begin{abstract}
The concept of debt financing has assumed considerable importance in recent years given the fundamental role debts now play in forming the financial structure of corporate firms. Quite evident in the debt finance literature is the juxtaposition between debt financing and corporate performance which suggests that debt financing can influence corporate performance. Against the narrow measures of debt financing which are common with most studies that have been carried out on the debt finance-performance dynamics; we attempted a more robust combination of debt finance choices in modelling for corporate performance. Based on data gleaned from the audited annual reports of fifteen (15) consumer goods firms listed in the Nigerian Stock Exchange (NSE) for the period 2006 to 2017, results of the panel regression technique revealed that total debt, long-term debt and short-term debt to asset ratios positively influence the performance of consumer goods firms in Nigeria. Based on the findings of the study, we recommend, among others, that there is need for the Nigerian firms to rely less on short-term debts, which forms the major part of their leverage, and focus more on developing internal strategies that can help improve their performance.
\end{abstract}

Keywords: Short term debts, Long term debts, Total Debts, Corporate Performance, Consumer goods.

long term debt. The financial system in emerging economies, including Nigeria, is punctuated with poor debt markets. The

\section{INTRODUCTION}

Corporate financing has somewhat become topical and attracted a great deal of public interest as a result of its significance regarding investment decisions and economic wellbeing of firms. Indeed, the topicality of the concept has manifested in various studies, both in the developed and emerging economies. Though in exhaustive, these studies have mainly emphasized the choice of debt against equity structure, otherwise referred to as firm's capital structure, with a single leverage variant the dominant variable. The idea of debt as a non-heterogeneous source of funds is a strong theoretical construct, but studies that transcend leverage decision and explore other dimensions of the debt choice are necessary. This is because the nature of debt finance and its incentive features can change with its maturity (short or long) and fund providers (capital markets or banks).

Therefore, it is essential that a study of debts structure involves an examination of the individual effects of all debt variants such as short-term debt, long-term debt and total debt due to their different risk and return profiles (Zuraidah et al., 2012). Moreover, using different components as measure of debt structure as against narrow measure will normally reveal occurrence of mismatch of funding by firms (Chen, 2004; Khan, 2012; Zeitun \& Tian, 2007), which can hardly be revealed by a constricted study of debt structure. Lucey and Zhang (2011) highlighted long and short term debt ratios as good measure of leverage ratios in developing countries because of the fund mismatch caused by limited external debt finance of most firms is mainly short term finance and greater reliance are placed on banks or other financial institutions for most of the external funds, thereby imposing extra burdens on the firms in the shape of exorbitant cost. This may account for the reasons why some scholars adopt different measures of debt ratio as against narrow measure of debt financial structure (For example, Chen, 2004; Khan, 2012; Ong Tze-Sam \& Heng, 2011; Zeitun \& Tian, 2007). Mismatching funds is when long term investments are financed by short term debts rather than long term debts.

Literature has shown that debt structure decisions are among the most important finance decisions firms encounter. The debate still remains until the present day whether such decisions influence costs of capital and firm values. According to Harelimana (2015), debt financing decision refers to the financial framework of debt levels maintained by an entity. It is vital to managers by reason of the fact that it constitutes the basis for making financing decisions in any firm. Basically, the choice of debt structure a firm adopts is both financial and marketing problem and it depends on the risk and return characteristics of such firm and/or its management (Tudose, 2012). Realistically, it is difficult to determine a firm's debt structure because the exact optimal debt mix can hardly be determined. For this reason, the firm must issue different securities in a countless mixtures to produce the combination that maximizes its overall value (San \& Heng, 2011), and increase performance. Optimal debt structure means a combination of funds which 
minimizes the weighted average cost of capital (WACC) and increases firm value.

The copious literature on the finance choice between debt and equity dwarfs studies on corporate debt structure/performance dynamics. In other words, while several studies abound on the determinants of financing mix (both debt and equity structure), relatively only a handful of them are on the effects of debt structure on corporate performance, especially in the developing countries. The work of Jensen and Meckling (1976) was one of the early studies on the interaction between capital structure and firm performance. However, over the last decades, a number of other studies have been performed to investigate the relation of financial leverage with firm performance, but empirical evidence regarding this relationship have been found to be contradictory and inconclusive. In this regard, two basic strands of findings exist in extant literature. Studies in the first strand, including those of John and Senbet (1998), Abor (2005), Zeitun and Tian (2007), Onaolapo and Kajolan(2010), and Taiwo and Olayinka, (2012) document positive relationship between debt financing and corporate performance. In the other strand, studies like Zeitun and Tian (2007), Ebaid (2009), Liew (2010), Majumdar and Sen (2010), and Luper and Kwanum (2012) report negative relationship between debt financing and firm performance. Although, some other studies, such as Shoaib (2012) and San and Heng, (2011) discover that most firms lack optimal debt financing structure because managers are not motivated to maximize corporate performance as their compensation are not performance oriented.

Due to these empirical inconsistencies, and given that most studies on the link between firm financial structure and performance are domiciled in the developed countries of Europe, America and Asia, a study based on empirical evidence from an emerging economy like Nigeria becomes warranted. The economies of the countries within these continents are reasonably stable, and so, it will be misleading to assume that results of studies carried out in those countries can be used to draw reliable conclusions on the emerging economies within the African continents because of the peculiarities associated with the different economies. For example, the regulatory framework, general business, legal and audit environment of the developed countries are very much different from those of the developing countries. All these factors could alter the result of a study. This means that country-specific findings will be important in provoking a global discourse of the association between debt financial and corporate performance. This is a gap in literature upon which our study is deeply rooted. In filling this gap, we attempted a robust combination of debt finance choices of short-term debt to asset ratio, long-term debt to asset ratio and total debts to asset ratio in modelling for corporate performance within the Nigerian environment.
The remainder of this paper is organized as follows: Section two provides the literature review on debt structure and firm performance. Section three discusses the theoretical framework for the study. Section four and section five focus on the methodology and analysis of results respectively. Lastly, section six concludes the study with some recommendations.

\section{LITERATURE REVIEW}

\subsection{Concept of Corporate Performance}

The term corporate performance refers to the benefits emanating from shares and those from the functioning and operational activities of a firm (Rouf, 2012). The performance a firm can be analysed via its financial statements such as the statements of financial position, comprehensive incomes, cash flow and statement of cash flows. Broadly speaking, the performance of a firm can be analysed via the use of financial ratios which express relationships between variables reported in financial statements of firms (Latridis, 2010). Financial ratios are useful and can meaningfully be used as performance measures when compared with other related meaningful information, either at present or past similar indicator(s) for the same firm or similar firms in the same industry.

According to Akle (2011), accounting-based measurements are generally considered as an effective indicator of a firm's performance. Accounting-based measurement indicates the profitability of firms on the short-term in the past years. Thus, it assists management is measuring the firm's overall efficiency. It is usually used as a measure for earnings generated by a firm during a period of time based on its level of sales, assets, capital employed, net worth and earnings. It is considered an indicator of growth, success and control. Shareholders also are interested in profitability since it indicates the progress and the rate of return on their investments

In the accounting literature, corporate performance can be measured by means of profitability indicators such as earnings per share (EPS), dividend per share (DPS), return on asset (ROA), return on equity (ROE), operating profit $(\mathrm{OP})$, return on capital employed (ROCE), profit margin $(\mathrm{PM})$, return on investment (ROI) or market-based measurement ratios like Tobin's $\mathrm{Q}$, market value added (MVA), market-to-book value (MTBV), annual stock return (RET) among others. In view of the aforementioned, this study shall focus on profitability measure of performance such as the return on asset (ROA).

\subsection{Debt Financing and Corporate Performance} Mizra (2013) identified capital structure as one of the internal dynamics that affect firm performance. Capital structure is to the ratio of debt and equity financing. In case of more debt financing, a firm has to face certain bankruptcy risk, but there are also some tax benefits associated with debt 
financing (Su \& Vo, 2010). A study by Oguna (2014) on the effect of capital structure on the financial performance of firms listed in the Nigerian Stock Exchange established that long-term debt had a significant negative relationship with return on equity, which means the leverage has effect in the long term but not short term. This study focused on the debt component of capital structure via the divide of total debts, long-term debts and short-term debts. Consequently, these debt components of capital structure (i.e. variables of the study) are briefly discussed.

\subsubsection{Long-term Debts and Corporate Performance}

Long-term debts show the percentage of assets financed with debt which is payable after more than one year. It includes bonds and long-term loans. Generally, these bonds and loans carry a higher interest rate, as lenders demand a higher return in exchange for taking on the greater risk of loaning money over a long period of time. In reality, long-term debt limits managerial discretion by making access to new funds and over-investment less likely (Hart \& Moore, 1995). A study by Hernandez-Canovas and Koeter-Kant (2008) suggests that the most significant variables in determining a firm's performance are the long-term debts. Empirical evidences such as Onoja and Ovayioza, (2015), Yan (2013); and Zeitun and Tian (2007) find clear evidence of a positive relationship between long-term debt and firms' performance variants of return on assets (ROA) and return on equity (ROE). On the other hand, Onaolapo \& Kajola (2010) found negative relationship between long-term debt and profitability, while Makanga (2015) reported a negative correlation between long-term debt and firm performance proxied by return on assets. Based on the review above, we therefore proposed the following hypothesis:

\section{$H_{O I}$ : There is no significant relationship between long term debts to asset ratio and corporate performance}

\subsubsection{Short-Term Debts and Corporate Performance}

In reality, the amount of outstanding short-term debts is an important measure of a firm's financial health. Short-term debt is the best financing tool since it is perceived to be cheaper or less costly for firms (Nwude, Itiri, \& Agbadua, 2016). According to Olaniyi, et.al (2015), short-term debt is an account shown in the current liabilities portion of a firm's statement of financial position and it comprises of any debt incurred by a firm that is due within a year period. The debt in a firm's liabilities account is usually made up of shortterm bank loans among other types. According to GarciaTerul \& Martinez-Solano (2007), short-term debt is positively correlated with firm's growth opportunities. Moreover, Onoja \& Ovayioza (2015) found that short-term debts are superior for limiting managerial discretion and reducing moral hazard on the firm's side. Equally, studies by Onoja \& Ovayioza (2015), Yan (2013); Weill (2008); and Zeitun \& Tian (2007) found evidence in support of a positive association between short-term debt and firms' profitability (as measured by return on assets). On the flip side, findings of the study carried out by Makanga (2015) revealed a negative but insignificant relationship between short-term debt and corporate performance (return on assets). Hence, we propose that:

$H_{O 2}$ : There is no significant relationship between short term debts to asset ratio and corporate performance

\section{.2.2.3 Total Debts and Corporate Performance}

Although, Khan (2012) and Amjed (2011) argue that the different types of debts instruments (such as short term debts, long term debt, or both of them) have different rate of returns investors will ask for, different risk element and by implication exert different impact on corporate performance, some researchers including Abor (2007) and Michaelas, Chittenden and Putziouris (1999) caution that determining a single optimal leverage level and trying to establish a relationship between the debt level and corporate performance is likely to result in spurious conclusions. The reason offered by Hutchinson et al., (1998) and Van der Wijst and Thurik, (1993) is that the effects of long and short term debts tend to cancel out if aggregated.

Sheikh and Wang (2011), examined non-financial firms listed on the Karachi Stock Exchange (KSE) in Pakistan and documented a negative relationship between total debt ratio and firm performance. On the other hand, Saeedi and Mahmoodi (2011) investigated the connection between capital structure and firm performance among firms listed on Tehran Stock Exchange and recorded a positive relation between debt ratio and firm performance. In a different study performed by Boroujeni et al (2013), both long term and total debt ratios were found to be positively correlated with firm performance. Makanga (2015) found a weak negative correlation between total debts and return on assets (performance). Based on the review above, we propose the following hypothesis:

$H_{O 3}$ : There is no significant relationship between Total debts to asset ratio and corporate performance

\subsubsection{Firm Size and Corporate Performance}

It is plausible that other factors may jointly influence debt financing or corporate performance and therefore cause spurious correlation (Richardson, Taylor \& Lanis, 2013). For this reason, firm size was included in this study as a control variable. This is essential because firm size accounts for the scale and scope of a firm's operations. Firm size is usually calculated by taking the logarithm of total assets. In this study, firm size is calculated by taking the logarithm of total assets. In the accounting literature, prior studies conducted by Mohammad \& Jaafer (2012); and Kebewar (2012) find clear evidence that corporate performance is positively related with firm size. On the basis of the findings of prior 
studies, we included firm size in our empirical model as a control variable.

\section{Theoretical Framework}

There are several theoretical paradigms which highlight the influence of debt on corporate performance, such as the agency cost theory (ACT), trade-off theory (TOT), signaling and liquidity risk theory (SLRT), pecking order theory (POT) and market timing theory (MTT). However, since studies that have been performed on the link between debt financing and corporate performance, we therefore anchor our work on the agency cost theory.

\section{Agency Cost Theory}

Jensen and Meckling (1976) built on the work Miller and Modigliani (1958) by developing agency costs theory. They assume that agency problems arise when shareholders (principals) and managers (agents) have divergent objectives or conflict of interest. That is, managers not accommodating the interests of shareholders. To monitor managers and constrain their excesses, shareholders may incur certain costs, called agency costs (Morri \& Beretta, 2008). Agency costs are costs meant to justify whether managers act consistently in line with contractual agreement of firm with the shareholders (Jensen \& Mackling, 1976). For an optimal debt level in the capital structure to be achieved, agency costs arising from the different interests of managers, debt holders and shareholders should be minimized (Jensen \& Mackling, 1976).

\section{Methodology}

\subsection{Analytical Framework}

As already noted, agency cost arises if there is conflict of interest between shareholders and their agents. Such conflicts are expected when managers have too much cash at their disposal and decide to use the excess cash for boost personal gains at the expense of creating wealth for shareholders and increasing firm's value (Weston \& Brigham, 1990). Conversely, managers with restricted "excess cash flow" due to their firms' debt commitments are less able to make such extravagant expenditures (Jensen, 1986). This means that the use of debt capital decreases the agency cost as payment of debts reduces the surplus cash. Therefore, the position of the agency cost theory is that debt capital in the form of short term loans or long term loans or both can reduce the excess cash at the hands of managers, reduce agency costs and consequently, improve corporate performance.

Flowing from the extant literature and theoretical review above, we expect a functional relationship between debt financing and corporate performance as represented in the following schema:

\section{Explanatory variable}

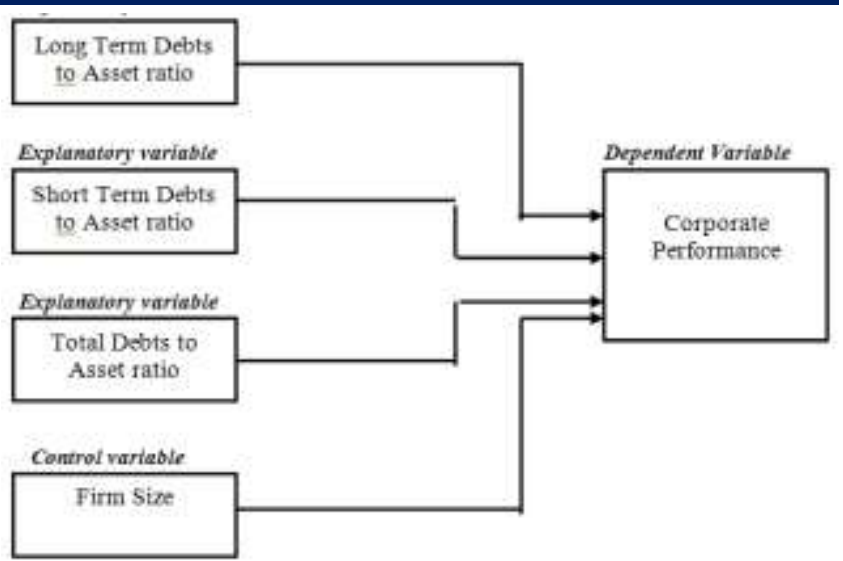

Figure 1: Research Analytical Framework, 2018) (Conceptualised by Researchers)

\subsection{Model Specification}

The model of this study is built on Maina \& Ishmail (2014) on the effect of capital structure on financial performance. However, the model for the study is modified not only to incorporate the effect of total debt on corporate performance, but also the effects of long term and short term debts on corporate performance, hence three (3) models were used with each testing the effect of the three scenarios (total, short-term and long-term debts) on corporate performance (return on asset). Each model took into cognizance, size of the firms. On the basis of the above, the relationship between debt financing and corporate performance is thus estimated in the following regression models:

$$
Y_{i t}=\alpha_{0}+\beta_{1} T A T S_{i t}+\beta_{2} S_{I Z E_{i t}}+e_{i t} \quad \text { eq. } 1 .
$$

Equation 1 above measures the effect of total debts on return on assets taking into cognizance the size of the firm.

$$
Y_{i t}=\alpha_{0}+\beta_{1} L T D S_{i t}+\beta_{2} S I Z E_{i t}+e_{i t} \quad \text { eq. } 2 .
$$

Equation 2 above measures the effect of long term debt on return on assets taking into cognizance the size of the firm.

$$
Y_{i t}=\alpha_{0}+\beta_{1} S T D S_{i t}+\beta_{2} S I Z E_{i t}+e_{i t} \quad \text { eq. } 3 .
$$

\begin{tabular}{|c|c|c|}
\hline \multicolumn{3}{|l|}{ Where: } \\
\hline $\mathrm{Y}_{\mathrm{it}}$ & $=$ & $\begin{array}{l}\text { Return on asset (ROA) for firm } i \text { in time } t \\
\text { as a measure of performance (Profit after } \\
\text { tax/Total assets) }\end{array}$ \\
\hline $\mathrm{SIZE}_{\mathrm{it}}$ & $=$ & Log of total assets for firm $i$ in time $t$ \\
\hline TATSit & $=$ & Total debt to asset ratio for firm $i$ in time $t$ \\
\hline \multicolumn{3}{|c|}{ (Total debt/Total assets) } \\
\hline $\operatorname{LTDS}_{\text {it }}$ & $=$ & $\begin{array}{l}\text { Long-term debt to asset ratio for firm } \mathrm{i} \text { in } \\
\text { time } \mathrm{t} \text { (Long term debts/Total assets) }\end{array}$ \\
\hline $\operatorname{STDS}_{\text {it }}$ & $=$ & $\begin{array}{l}\text { Short-term debt to asset ratio for firm } \mathrm{i} \text { in } \\
\text { time } \mathrm{t} \text { (Short term debts/Total assets) }\end{array}$ \\
\hline
\end{tabular}

Equation 3 above measures the effect of short term debt on return on assets taking into cognizance the size of the firm. 
International Journal of Academic Accounting, Finance \& Management Research (IJAAFMR)

ISSN: 2000-008X

Vol. 3 Issue 5, May - 2019, Pages: 26-34

$\begin{array}{lll}\mathrm{e}_{\mathrm{it}} & = & \text { Error term } \\ \alpha & = & \text { Constant term } \\ \beta^{\mathrm{S}} & = & \text { Coefficients of the explanatory variables }\end{array}$

\subsection{Research Design, Sampling and Data Estimation} Technique

This study employed ex-post facto research design. This research design was adopted because it seeks to analyse secondary data which can hardly be manipulated by the researchers. The population of the study comprises the entire 45 manufacturing firms quoted on the Nigerian Stock Exchange (NSE) as at 31 December, 2017. But, since our population of interest covers only the listed consumer goods firms in Nigeria, the target population becomes the entire 22 consumer goods firms quoted on the Nigerian Stock Exchange (NSE). The consumer goods subsector was chosen over others because it is one of the least investigated sectors of the NSE. To cut costs, a representative sample size of 20 firms derived using the Yamani's (1967) scientific approach to sample determination was adopted.

To ensure that the 20 sample firms are given equal opportunity of being selected, the probabilistic sampling approach was adopted with emphasis on a simple random sampling technique. However, a final sample size of 15 consumer goods firms was selected based on certain criteria: The first criterion was that sample units included in the study hold a complete twelve years financial statement data. Therefore, firms with missing data for a period covering twelve years from 2006 to 2017 were excluded from the study. Secondly, firms that ceased operation at any point during the period of study were excluded. The statistical formula is stated as follows:

$$
n=\frac{N}{1+N\left(e^{2}\right)}
$$

Where: $n=$ sample size

$N=$ population size (target)

$e=$ level of significance desired ( 0.05 on the basis of

95\% confidence level)

Data used for analysis in the study were extracted from the published financial statements of the firms covering a period of 12 years from 2006 to 2017. This was supported, where required, with the financial information of the firms as contained in the Nigeria Stock Exchange (NSE) fact book. Both descriptive statistics (such as mean, standard deviation, and minimum, maximum) and inferential statistics (such as the panel regression model) were used to analyse the study data. The data obtained were subjected to regression analysis via STATA 13.0 version. Moreover, to establish the accuracy of the research model, we performed the classical regression assumption test of normality, heteroskedasticity, multi-collinearity and serial correlation. The panel regression technique was employed to enable us investigate the connection between corporate performance (dependent variable) and (explanatory variables) debt financing over 12 years (time series) with a sample of listed firms (crosssection).

\section{Presentation and Analysis of Result}

\subsection{Descriptive Statistics}

Presented in Table 4.1 is the descriptive statistics of the dependent (return on asset: ROA), independent (total debts to assets ratio, long term debts to assets ratio and short term debts to assets ratio) and control (firm size) variables.

Table 4: Descriptive Statistics (Dependent, Independent and Control Variables)

\begin{tabular}{|c|c|c|c|c|c|}
\hline Vartable & Chas: & Math & stt. Dev, & Min & $\operatorname{Max}$ \\
\hline ros & 180 & 6.296333 & 16.41057 & -15.99 & 28.57 \\
\hline tats & 180 & 1.561056 & .6512831 & .01 & 3.06 \\
\hline Itds & 180 & 1.253222 & .3855166 & .61 & 2.87 \\
\hline stds & 180 & .3018333 & .1944604 & 77. & 1,2 \\
\hline size & 130 & $5,12466 ?$ & 692228 & 3.28 & 6.33 \\
\hline
\end{tabular}

Source: Researchers' Computation, 2018

It can be seen that the mean value of ROA, TATS, LTDS, STDS and SIZE are 6.2963, 1.5610, 1.2532, 0.3078 and 5.1246 respectively with standard deviations of 14.4805 , $0.4512,0.3855,0.1944$ and 0.6822 respectively. The maximum value of the variables was recorded by ROA with value 28.57 and its minimum value $(-88.99)$. The descriptive statistics of mean and standard deviation implies that the variables are relatively clustered around the mean of $6.3 \%$, $1.6 \%, 1.3 \%, 0.31 \%$ and $5.1 \%$ for ROA, TATS, LTDS, STDS and SIZE respectively.

\subsection{Correlation Analysis}

Presented in Table 4.2 is the correlation matrix of the dependent, independent and control variables of the study. The correlation matrix is used to establish if there is multicollinearity between pairs of independent variables (TATS, LTDS, and STDS).

\section{Table 4.2: Correlation Matrix (Dependent, Independent and Control Variables)}

\begin{tabular}{|c|c|c|c|c|c|}
\hline & soa & alaes & tata & $254 a$ & $x$ tha \\
\hline$=04$ & 1.0000 & & & & \\
\hline s12t & 0.3512 & 1.0000 & & & \\
\hline tats & -0.1122 & 0.0397 & 1.0000 & & \\
\hline Itoda & 0.0042 & 0.0855 & Q.9035 & 1.0000 & \\
\hline atda & -0.2651 & -0.0763 & 0.5299 & 0.1155 & 1.0000 \\
\hline
\end{tabular}

Source: Researchers' Computation, 2018

It can be seen that there is multicollinearity among the variables of the variable since the Pearson correlation coefficient exceeds 0.8 . This position was further resolved by the Breusch-Pagan/Cook-Weisberg test for heteroskedasticity.

Table 4.3: Heteroskedasticity Test Results 


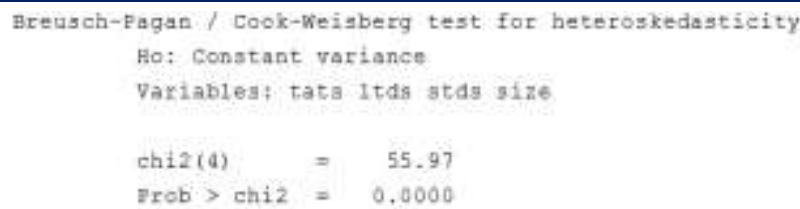

The Breuch-Pagan/Cook-Weisberg test for heteroskedasticity revealed that there is the absence of heteroskedasticity among variables of the study as evidence in the Chi2 (4) $=55.97$ with Prob. $>$ chi $2=0.0000$.

\section{$5.3 \quad$ Test of Hypotheses}

\section{Hypothesis I}

$H_{O 1}$ : There is no significant relationship between longterm debts to asset ratio and corporate performance

Table 4.5: Regression Results of Long Term Debts to Asset Ratio (LDTS) and Return on Assets (ROA)

\begin{tabular}{|c|c|c|c|c|c|}
\hline seirce & 35 & af & MS & Hustet of abs - & 189 \\
\hline 3ode1. & 4636.92798 & 2 & 2383.46394 & Prot $>F$ & $=0.5002$ \\
\hline Eesidunl & $32479.426 ?$ & 117 & IBs. 357243 & E-2quared & 0.1262 \\
\hline & $7 x^{4}$ & 17 & 8 & Adj B-squited = & $=0.2164$ \\
\hline
\end{tabular}

\begin{tabular}{|c|c|c|c|c|c|c|}
\hline 207 & Caet. & Sta. Ier. & t. & polti & 5951 Cont. & Isterva1] \\
\hline lest & -.773063 & 2.658149 & -7.37 & 0.713 & -6.271909 & 4.255996 \\
\hline size & t.501779 & 1.450635 & $9.0 t$ & 0.260 & 4.544131 & $18.4 \div 939$ \\
\hline coss & $-10, \$ 2213$ & 0.265529 & $-3,79$ & 0.690 & $=47,13 \% 21$ & $-14,25304$ \\
\hline
\end{tabular}

Source: Researchers' computation, 2018

Presented in Table 4.5, is the regression result of long term debts to assets ratio (LTDS) and return on asset (ROA) of the selected consumer goods firms quoted on the Nigerian Stock Exchange during 2006-2017. The R-squared for LTDS is 0.1240 , indicating that the independent explains about $12.40 \%$ of the systematic variations in ROA for the selected consumer goods firms quoted on the Nigerian Stock Exchange. The f-ratio indicates that long term debts to assets ratio $(\mathrm{LTDS}=12.53$; Prob $<\mathrm{f}=0.0000)$ significantly affects return on asset (ROA). In addition, the p-value of LTDS $(0.0000)$ is an indication that there is significant relationship between long term debts to assets ratio and return on asset of the selected quoted consumer firms in Nigeria.

Since the Prob. F (0.0000) is lesser than $0.05 \%$ level of significance, we therefore reject the null hypothesis and accept the alternate hypothesis which suggests that long-term debts to asset ratio have significant effect on corporate performance of quoted manufacturing firms in Nigeria. This finding is in tandem with the position of Onoja and Ovayioza, (2015) and Yan (2013) who found clear evidence of a positive relationship between long-term debt and firms' performance.
Hypothesis II

$H_{O 2}$ : There is no significant relationship between shortterm debts to asset ratio and corporate performance

Table 4.6: Regression Results of Short Term Debts to Asset Ratio (STDS) and Return on Assets (ROA)

\begin{tabular}{|c|c|c|c|c|c|c|c|}
\hline Avusce & 58 & At & \multicolumn{2}{|c|}{ m } & & \multirow{2}{*}{ 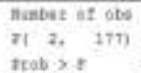 } & \multirow{2}{*}{$\begin{array}{l}=150 \\
=\quad 12.69 \\
=0.0020\end{array}$} \\
\hline mosel 1 & Eา78.8355? & 2 & 3386 & 94977 & & & \\
\hline Eenideal & $20780: 113$ & דוני & 233. & 0921 & & R-squazed & - 0:223s \\
\hline Tatal & गТम, К⿻4 & 370 & 209. & טE⿱一⿻上丨) & & Anos $k=$ & $=13.313$ \\
\hline sat & cuef: & atd. & $\mathrm{t} x$ & $=$ & Dotei & [954 Dens. & intertes:] \\
\hline atta & -17.25501 & 5. $a t:$ : & & -3.51 & 6,061 & $-27,07576$ & -1.225:55 \\
\hline nine & 7,046726 & $1.44 \pi$ & 1591 &,+ 13 & 0.900 & 4. $2077 \%$ & 9.924:It: \\
\hline sens & -26.12525 & 3.260 & & -5.15 & 0.062 & -28.74421 & -9.05456 \\
\hline
\end{tabular}

Source: Researchers' computation, 2018

Presented in Table 4.6, is the regression result of short term debts to assets ratio (STDS) and return on asset (ROA) of the selected consumer goods firms quoted on the Nigerian Stock Exchange during 2006-2017. The R-squared for STDS is 0.1805 , indicating that the independent explains about $18.05 \%$ of the systematic variations in ROA for the selected consumer goods firms quoted on the Nigerian Stock Exchange. The f-ratio indicates that short term debts to assets ratio $(\mathrm{STDS}=19.49$; Prob $<\mathrm{f}=0.0000)$ significantly affects return on asset (ROA). In addition, the p-value of STDS (0.0000) is an indication that there is significant relationship between short term debts to assets ratio and return on asset of the selected quoted consumer firms in Nigeria.

Since the Prob. F (0.0000) is lower than $0.05 \%$ level of significance, we therefore reject the null hypothesis and accept the alternate hypothesis, suggesting that short-term debts to asset ratio have significant effect on corporate performance of quoted consumer goods firms in Nigeria. This means that the result of the study is consistent with the findings of Garcia-Terul and Martinez-Solano (2007), Yan (2013) and Weill (2008) who reported evidence in support of a positive association between short-term debt and firms' profitability (as measured by return on assets).

Hypothesis III

$\mathrm{H}_{\mathrm{O} 3}$ : $\quad$ There is no significant relationship between total debts to asset ratio and corporate performance

Table 4.4: Regression Results of Total Debts to Asset Ratio (TATS) and Return on Assets (ROA) 
International Journal of Academic Accounting, Finance \& Management Research (IJAAFMR) ISSN: 2000-008X

Vol. 3 Issue 5, May - 2019, Pages: 26-34

\begin{tabular}{|c|c|c|c|c|c|}
\hline Spetrtes & 53 & df & 149 & Nunbet of obs & 710 \\
\hline ModeI & 5219.73731 & 2 & 2609.76960 & Dxob $x=8$ & $\begin{array}{r}14.29 \\
0.0000\end{array}$ \\
\hline aesideal & 2875. 2574 & 117 & 192.571349 & H-Aeteared & 0.1390 \\
\hline Total & 39513.9546 & IJy & 204.696397 & Rost stis & -13.512 \\
\hline
\end{tabular}

\begin{tabular}{|c|c|c|c|c|c|c|}
\hline roa & Eot. & Ste. $3 \mathrm{rr}$. & $t$ & $E>|t|$ & $194 x$ cont. & Interra2] \\
\hline tots & $-4,82899 y$ & 2.235668 & -1.10 & 0.074 & $-1.44260 T$ & .2965131 \\
\hline size: & 7,560101 & 1.481505 & 5.10 & 0.005 & 4. 636421 & \pm 0.54379 \\
\hline conta & -25.16657 & 8.292935 & -1.16 & 0.002 & -11.53236 & -3.10277 \\
\hline
\end{tabular}

Source: Researchers' Computation, 2018

Presented in Table 4.4, is the regression result of total debts to assets ratio (TATS) and return on asset (ROA) of the selected consumer goods firms quoted on the Nigerian Stock Exchange during 2006-2017. The R-squared for TATS is 0.1390 , indicating that the independent explains about $13.90 \%$ of the systematic variations in ROA for the selected consumer goods firms quoted on the Nigerian Stock Exchange. The f-ratio indicates that total debts to assets ratio (TATS $=14.29$; Prob $<\mathrm{f}=0.0000)$ significantly affects return on asset (ROA). In addition, the p-value of TATS $(0.0000)$ is an indication that there is significant relationship between total debts to assets ratio and return on asset of the selected quoted consumer firms in Nigeria.

Since the Prob. F (0.0000) is lesser than $0.05 \%$ level of significance, we therefore reject the null hypothesis and accept the alternate hypothesis which states that there is significant relationship between total debts to asset ratio and corporate performance of quoted consumer goods firms in Nigeria. Similar result was documented by Boroujeni et al (2013), although, Makanga (2015) recorded a weak negative correlation between total debts and firm performance.

\section{CONCLUSION AND RECOMMENDATIONS}

The primary objective of this study was to investigate the relationship between debt financing and corporate performance. To achieve this objective, we used 180 firmyear observations in a panel data form for 15 consumer goods firms listed on the Nigerian Stock Exchange from 2006 to 2017. We proxy corporate performance using return on assets (ROA), which was calculated as profit after tax scaled by total assets. Component of debt financing adopted as explanatory variables for the present study are total debts, long term debts and short term debts.

Results of the study show that all three debt ratios exert positive and significant impact on corporate performance of listed consumer goods firms in Nigeria for the periods studied. Based on the findings of the study, we recommend that listed consumer goods firms in Nigeria should seek to balance the trade-off between the benefits of debt and bankruptcy costs. This implies that a firm needs to choose debt ratio at certain proportion to be better off. Finally, firms should rely less on short-term debt, which forms the major part of their leverage, and focus more on developing internal strategies that can help improve their accounting performance as their performance for the period studied was very low.

\section{REFERENCES}

1. Abor, J. (2005). The effect of capital structure on profitability: an empirical analysis of listed firms in Ghana. The Journal of Risk Finance, 6(5), 438-445.

2. Abor, J. (2007). Debt policy and performance of SMEs: evidence from Ghanaian and South Africa firms. Journal of Risk Finance, 8, 364-379.

3. Akle, Y. H. (2011). The relationship between corporate governance and financial reporting timeliness for companies listed on Egyptian stock exchange: an empirical study. Internal Auditing and Risk Management, 2(22), 1-13

4. Amjed, S. (2011). Impact of financial structure on firm's performance. Society of Interdisciplinary Business Research (SIBR), 454-476

5. Boroujeni, H. N., Noroozi, M., Nadem, M. \& Chadegani, A. (2013). The Impact of capital structure and ownership structure on firm performance: a case study of Iranian companies. Journal of Applied Sciences, Engineering and Technology, 6(22), 4265-4270.

6. Chen, J. J. (2004). Determinants of capital structure of Chinese-listed companies. Journal of Business Research, 52 (12) 1341-1351.

7. Ebaid, E.I. (2009). The impact of capital-structure choice on firm performance: empirical evidence from Egypt. The Journal of Risk Finance, 10(5), 477-487.

8. Garcis-Teruel, P. J. \& Martinez-Solano, P. (2007). Short-term debt in Spanish SMEs. International Small Business Journal, 25 (6), 579-602.

9. Harelimana, J.B. (2015). Effect of debt financing on business performance: A comparative study between I\&M bank and bank of Kigali, Rwanda. Global Journal of Management and Business Research: C Finance, 17(2), 37-45.

10. Hart, O. \& Moore. J. (1995). Debt and Seniority: an Analysis of the role of hard claims in constraining management. American Economic Review, 567-585.

11. Hernandez-Canovas, G. \& Koeter-Kant, H. (2008). Debt maturity and relationship lending, International Small Business Journal, 26 (5), 595617.

12. Hutchinson, P., Hall. G. \& Michaelas. N. (1998). The determinants of capital structure for micro, small and medium-sized enterprise, proceedings of the 43rd annual world conference of the International Council for Small Business, Nanyang Technological University, Singapore, 1-9. 
13. Jensen, M. (1986). Agency costs of free cash flow, corporate finance, and takeovers. American Economic Review, 76, 323-329.

14. Jensen, M.C. \& Meckling, W.H. (1976). Theory of the firm: Managerial behavior, agency costs and ownership structure, Journal of Financial Economics, 3(4), 305-360.

15. John, K. \& Senbet, L. W. (1998). Corporate governance and board effectiveness. Journal of Banking \& Finance, 22(4), 371-403.

16. Khan, A. (2012). The relationship of capital structure decisions with firm performance: a study of the engineering sector of Pakistan. International Journal of Accounting and Financial Reporting, 2(1), $45-262$

17. Latridis, G. (2010). IFRS adoption and financial statement effects: The UK case.International Research Journal of Finance and Economics, 38, 165-172.

18. Lucey, B.M. \& Zhang, Q. (2011). Financial integration and emerging markets capital structure. Journal of Banking \& Finance, 35(5), 1228-1238.

19. Luper, L. \& Kwanum, I. M. (2012). Capital structure and firm performance: evidence from manufacturing companies in Nigeria. International Journal of Business and Management Tomorrow, 2(5), 1-7.

20. Maina, L. \& Ishmail, M. (2014). Capital structure and financial performance in Kenya: Evidence from firms listed at the Nairobi Securities Exchange. International Journal of Social Sciences and Entrepreneurship, 1 (11), 209-223.

21. Majumdar, S. K. \& Sen, K. (2010). Debt in the Indian corporate sector: Its effects on firm strategy and performance. Public Choice, 130 (2), 209-223.

22. Makanga, A.M. (2015). The effect of debt financing on the financial performance of companies listed at the Nairobi Securities Exchange. A research project presented in partial fulfilment of the requirements for the award of Master of Business Administration, School of Business, University of Nairobi, 1-69.

23. Michaelas, N., Chittenden, F. \& Putziouris, P. (1999). Financial policy and capital structure choice in UK SMEs: empirical evidence from company panel data. Small Business Economics, 12, 113-130.

24. Miller, M.H. \& Modigliani F. (1958). The cost of capital, corporate finance, and the theory of investment. American Economic Review, (48), 261297

25. Mirza, S.A \& Javed, A. (2013). Determinants of financial performance of a firm: Case of Pakistani stock market. Journal of Economics and International Finance, 5(1), 43 -52.

26. Modigliani, F., \& Miller, M. H. (1958). The Cost of Capital Corporation Finance and the Theory of
Investment. The American Economic Review, 3, 261-297.

27. Mohammad, T. \& Jaafer, A. (2012). The relationship between capital structure and profitability. International Journal of Business and Social Science, 3(16), 1-17

28. Morri G., \& Beretta, C. (2008). The capital structure determinants of REITs. Is it a peculiar industry? Journal of European Real Estate Research, 1(1), 6-57.

29. Nwude, C.E., Itiri, I. O., Agbadua, B. O. \& Udeh, S. N. (2016). The impact of debt structure on firm performance: Empirical evidence from Nigerian quoted firms. Asian Economic and Financial Review, 6(11), 647-660

30. Oguna, A. (2014). Examining the effect of capital structure on financial performance: a study of firms listed under manufacturing, construction and allied sector at the Nairobi Securities Exchange. Available online at http://erepository.uonbi.ac.ke/handle/11295/78432

31. Olaniyi, T.A., Elulu, M.O. \& Abdusalam, T.S. (2015). Impact of capital structure on corporate performance: a pre and post crisis evaluation of selected companies in US. International Journal of Accounting Research, 2(8), 1-19

32. Onaolapo, A. A. \& Kajola, S.O. (2010). Capital structure and firm performance: evidence from Nigeria. European Journal of Economics, Finance and Administrative Sciences, 25, 70-77.

33. Ong Tze San \& Boon Heng. (2011). Capital structure and corporate performance of Malaysian construction sector. International Journal of Humanities and Social Science, 1(2), 28-36.

34. Onoja, E. E. \& Ovayioza, S. P. (2015). Effects of debt usage on the performance of small scale manufacturing firms in Kogi State of Nigeria. International Journal of Public Administration and Management Research, 2(5), 74-84.

35. Richardson, G., Taylor, G., \& Lanis, R. (2013). The impact of board of director oversight characteristics on corporate tax aggressiveness: An empirical analysis. The Journal of Accounting and Public Policy, 32, 68-88.

36. Rouf, A. (2012). The financial performance and corporate governance disclosure: A study in the annual reports of listed companies of Bangladesh. Pak. J. Commer. Soc. Sci. 6(1), 1-11.

37. Saeedi, A. \& Mahmoodi, I. (2011). Capital structure and firm performance: evidence from Iranian companies. International Research Journal of Finance and Economics, 1(70), 20 -26.

38. San, O. T \& Heng, T. O. (2011). Capital structure and corporate performance of Malaysian construction sector. International Journal of Humanities and Social Sciences, 1(2), 28-37. 
39. Sheikh, N. \& Wang, Z. (2011). Determinants of capital structure: an empirical study of firms in manufacturing industry of Pakistan. Managerial Finance, 37(2), 117-133.

40. Shoaib, M. M. (2012). Impact of capital structure on firms' financial performance: Evidence from Pakistan. Journal of Finance, 17(5), 56-101.

41. Su, G. \& Vo, H.T. (2010). The relationship between corporate strategy, capital structure and firm performance: an empirical study of the listed companies in Vietnam. Int. Res. J. Finance. Econ., $50,2-9$.

42. Taiwo, A. \& Olayinka, A. (2012). Profitability and leverage: Evidence from Nigerian firms. Global Journal of Business Research, 6(1), 17-22.

43. Tudose, M.B. (2012). Capital structure and corporate performance. Economy Transdisciplinarity Cognition, 15(2), 76-82.

44. Tze-Sam, D.O. \& Heng, T.B. (2011). Capital structure and corporate performance of Malaysian construction sector. International Journal of Humanities and Social Science, 1(2), 28-36

45. Van der Wijst, N. \& Thurik,R. (1993). Determinants of small firm debt ratios: an analysis of retail panel data. Small Business Economics, $5(1), 55-65$.

46. Weill, L. (2008). Leverage and corporate performance: Does institutional environment matter? Small Business Economics, 30:.251-265.

47. Weston, F, J . \& Brigham, E.F. (1990). Managerial Finance, Holt, Rinehart and Winston, N.Y.15

48. Yan, B. (2013). An analysis of the factors affecting debt financing structure: empirical evidence from Chinese listed companies. Journal of Jinan University, 4(3), 1-19

49. Zeitun, R. \& Tian, G. (2007). Capital structure and corporate performance: evidence from Jordan. Australian Accounting and Finance Journal, 1(4), 40-67.

50. Zuraidah, A., Norhasniza, M.H.A., \& Shashazrina, R. (2012). Capital structure effect on firms' performance: focusing on consumers and industrials sectors on Malaysian firms. International Review of Business Research Papers, 8(5), 137-155. 